\title{
Los orígenes latinoamericanos de Podemos
}

\author{
Manuel Alcántara Sáez y José Manuel Rivas Otero (Dirs.)
}

Madrid: Tecnos. 2019. 188 páginas.

\section{Francisco Olucha-Sánchez}

DOI: https://doi.org/10.46468/rsaap.14.1.R1

En los últimos años, la irrupción de actores políticos en el espacio político ha generado un interés en el estudio en diferentes ámbitos de la ciencia política. La formación política Podemos ha conseguido la transformación del sistema de partidos español instaurado desde los años ochenta. Podemos consiguió que parte de su electorado viniese de fuerzas políticas totalmente diferentes a las posiciones ideológicas del partido y de un núcleo importante de abstencionistas (Fernández Albertos, 2015), desbordando la escala izquierda-derecha. Sin embargo, el paso del tiempo de la formación política fue asentando posiciones ideológicas con una clara predisposición ideológica (Marcos-Marne et.al., 2019). De esta forma, Podemos pasó a formar parte de la configuración del sistema de partidos español.

La producción académica sobre el éxito de Podemos ha sido muy variada, pero ningún estudio se ha centrado en la influencia que tuvieron sus miembros fundadores en la conformación exitosa de un partido político en el sistema de partidos español. En Los orígenes latinoamericanos de Podemos, dirigido por Manuel Alcántara y José Manuel Rivas, los autores hacen un viaje a las raíces académicas y políticas de los miembros más destacados de Podemos y a su relación con América Latina, en especial allí donde se dieron los procesos políticos de la llamada "marea rosa"
(Panizza, 2009). Como explican los directores en la Introducción, el libro hace un buceo por la producción académica, la militancia política y las experiencias profesionales de los fundadores de este partido, con el objetivo de indagar en los elementos que han aprendido en su formación como académicos y políticos en América Latina. Alcántara y Rivas remarcan que la relación entre España y América Latina siempre ha sido especial, pero se trata de la primera vez en la historia que los miembros de una fuerza política española llevan a la práctica sus conocimientos y experiencia adquiridos en América Latina.

En el primer capítulo del libro, José Manuel Rivas examina las influencias académicas y las fuentes bibliográficas de la producción de los tres principales líderes del Podemos en sus inicios: Pablo Iglesias, Iñigo Errejón y Juan Carlos Monedero. El autor muestra que los pensamientos que permean sus experiencias políticas y, posteriormente, sus trabajos académicos tienen su origen en pensadores latinoamericanos y/o han tenido presente la región latinoamericana como escenario político en sus investigaciones. Además, a través de su lectura se puede apreciar que los tres líderes de Podemos tenían diferentes autores de referencia y, por lo tanto, diferentes perspectivas teórico-políticas que se visibilizarán en la construcción de Podemos como herramienta política. 
En el siguiente capítulo, Agustín Haro aborda estas perspectivas para hacer un análisis del discurso de Podemos desde sus inicios hasta las elecciones generales del 20 de diciembre de 2015. El autor escoge diferentes discursos en momentos claves desde el nacimiento del partido (la Asamblea denominada Vistalegre I) hasta las elecciones generales de 2015. Durante este tiempo se perfila la evolución discursiva de Podemos aplicando las fórmulas políticas aprendidas en sus experiencias latinoamericanas y la reivindicación de conceptos esenciales en la construcción política del partido como "patria" o "pueblo".

En el tercer capítulo, Gemma Ubasart-González y Salvador Martí i Puig reconstruyen la historia de vida de los diferentes miembros del cuerpo ejecutivo más alto del partido en sus inicios, el Consejo de Coordinación de Podemos. Los autores describen el contexto en el que se politizan los miembros de la organización al igual que su influencia militante en el ámbito académico. Ubasart-González y Martí i Puig destacan que los movimientos estudiantiles de finales de los años noventa y principios del siglo XXI, su experiencia laboral en América Latina y el escenario post 15-M incidirán en su producción académica.

Por otro lado, el capítulo 4, escrito por Antolín Sánchez Jorge, combina el contexto político y socioeconómico de América Latina con las experiencias de asesoramiento político de los líderes de Podemos. De esta manera, el autor contextualiza el surgimiento de Podemos como un partido-movimiento que tiene como objetivo una búsqueda de la transversalidad que supere la tipología de los partidos tradicionales y la división entre izquierda y derecha. Sánchez
Jorge concluye que los líderes de Podemos se desmarcan, también, de la izquierda ortodoxa.

El último capítulo de la primera parte del libro, escrito por Rubén Martínez Dalmau, aborda el origen y el desarrollo de la Fundación CEPS, y cómo se fue fraguando la relación de asesoramiento de los académicos españoles con los gobiernos latinoamericanos, especialmente en los procesos constituyentes. El papel que jugó la fundación CEPS en estos procesos fue, en la perspectiva del autor, la de interactuar con diversos actores políticos (partidos, movimientos sociales y personas a título individual). Además, los miembros de la Fundación CEPS fueron observadores de primera línea de los cambios políticos que se produjeron en América Latina en la primera década del siglo XXI.

La segunda parte del libro está basada en estudios de caso de los países en los cuales los principales líderes de Podemos han tenido sus experiencias políticas y académicas. En el primer capítulo de esta sección (capítulo 6), Julián Martínez Ramos se centra en los movimientos sociales y en Ecuador, en donde se produjeron algunos de los contratos de asesoramiento en la reforma del Estado con la colaboración de miembros de Podemos. Al analizar el caso ecuatoriano, el autor remarca la falta de transparencia en su búsqueda de los documentos pertinentes.

En el último capítulo, Esther del Campo y Jorge Resina de la Fuente analizan el caso de Bolivia, cuyo proceso político es, según los autores, el más influyente en términos políticos y académicos en los líderes de Podemos. Especialmente en Iñigo Errejón, quien elabora su tesis doctoral sobre la hegemonía a través del discurso del el Mo- 
vimiento Al Socialismo (MAS). Asimismo, del Campo y Resina de la Fuente indican que Álvaro García Linera, vicepresidente de Bolivia durante todo el gobierno del MAS, es uno de los intelectuales que más influencia tienen en los líderes de Podemos. La construcción del pueblo a través de la diversidad de la lucha de los movimientos sociales, el momento destituyente y el posterior proceso constituyente son algunas de las ideas políticas que los dirigentes de Podemos adquirirán de su experiencia política en Bolivia.

Las conclusiones a cargo de Manuel Alcántara suponen un punto de inflexión sobre líneas de investigación a futuro. En primer lugar, Alcántara señala que los líderes de Podemos son parte de esa escuela de cuadros políticos que se han formado en la Facultad de Ciencias Políticas y Sociología de la Universidad Complutense de Madrid de la que forman parte algunos ilustres políticos españoles y latinoamericanos. En segundo lugar, el autor pone en valor la tradición académica latinoamericana como un insumo fundamental -más allá de otras influencias- del que se nutrieron los líderes de Podemos.

Para concluir, puede afirmarse que el libro versa en gran medida sobre la influencia de los diversos actores y procesos políticos latinoamericanos en la construcción de Podemos. A pesar de que se citan diversas obras e intelectuales que influyen en los líderes de Podemos, todos los autores destacan a Ernesto Laclau y Chantal Mouffe por dos premisas políticas que se llevan a cabo en la construcción de Podemos. La primera es la ruptura del eje izquierda y derecha al tratar de imponer el eje arriba-abajo (élite versus pueblo) y la construcción de un pueblo (Laclau, 2005). La segunda remite a la resignificación de conceptos claves para llegar a diferentes sectores de la población (Laclau y Mouffe, 1987). Los autores señalan las influencias teórico-políticas enmarcadas en un espectro académico concreto en la confección de Podemos, que más tarde cristalizarán en diferentes corrientes políticas internas. Por lo tanto, las futuras investigaciones sobre Podemos tendrán un valioso material en este libro, ya que podrán encontrar las diversas influencias políticas e intelectuales latinoamericanas, en las cuales se han basado sus fundadores a la hora de construir dicha formación política.

\section{Referencias bibliográficas}

Fernández Albertos, J. (2015). Los votantes de Podemos. Madrid: Catarata.

Laclau, E. (2005). La razón populista. Buenos Aires: Fondo de Cultura Económica.

Laclau, E. y C. Mouffe. (1987). Hegemonía y estrategia socialista. Hacia una radicalización de la democracia. Madrid: Siglo XXI.

Marcos-Marne, H., C. Plaza-Colodro,y T. Freyburg (2019). Who votes for new parties? Economic voting, political ideology and populist attitudes. West European Politics, 43 (1), 1-21.

Panizza, F. (2009). Nuevas izquierdas y democracia en América Latina, Revista CIDOB d'Afers Internacionals, 85/86, 75-88. 